Journal Universitas Muhammadiyah Gresik Engineering, Social Science, and Health International Conference (UMGESHIC)

UMGCINMATIC : $1^{\text {st }}$ Rethinking Education during Covid-19 Era: Challange and Innovation

\title{
THE EFFECT OF HEDONIC SHOPPING MOTIVATION ON IMPLUSIVE BUYING: THE MEDIATOR ROLES OF SHOPPING LIFESTYLE
}

\author{
Maulia Kirana Fadhilah ${ }^{1}$, Asri Rejeki², Noer Suci Endah Puspitaningrum \\ ${ }^{1,2,3}$ Psychology Faculty, Muhammadiyah Gresik University
}

\section{$\underline{\text { kiranafadhilah2407@gmail.com¹ }}$, rejeki.asri@yahoo.com ${ }^{2}, \underline{\text { nse.puspitaningrum@umg.ac.id }}{ }^{\mathbf{3}}$}

\begin{abstract}
This study aims to determine the effect of hedonic shopping motivation on impulsive buying with a shopping lifestyle mediator on shopee consumers. This study used a quantitative approach using incidental sampling techniques and obtained a sample of 81 students from the Faculty of Economics and Business, Faculty of Teacher Training and Education, Faculty of Psychology, Univ Muhammadiyah Gresik, Class of 2017. The data collection method for hedonic shopping motivation, impulsive buying and shopping lifestyle variables used a questionnaire that compiled and modified by researchers in a Likert Scale. Test the validity of the scale using content validity. Scale reliability test using Alpha Cronbach technique. Data analysis using Multiple Regression based on Baron and Kenny (1986). The results of the analysis show that path $c$ is accepted with a significant value of 0.000 ( $p<0.05)$, path a is not accepted with a value of 0.205 ( $p>0.05)$, path $b$ is not accepted with a value of $0.596(p>0.05)$, and path $b$ is not accepted with a value of 0.596 ( $p>0.05)$, and path $c^{\prime}$ is not accepted with a value of $0.432(p>0.05)$ getting a perfect mediation result. Subjects have a high category on the impulsive buying variable, a medium category on the hedonic shopping motivation variable and a low category on the shopping lifestyle variable.
\end{abstract}

Keywords: Hedonic Shopping Motivation, Implusive Buying, Shopping Lifestyle, College Student. 


\section{INTRODUCTION}

Along with the development of the times and increasing modern technology, people's activities have changed, one of which is in terms of people's buying behavior. With the advent of internet-based technology it has become a part of life. Many business people in Indonesia use the internet as a place for buying and selling transactions. The internet is an information technology so that people use the internet to browse information on a product or service and make purchases or transactions online, business transactions using the internet another term is E-Commerce. According to the World Trade Organization, E-Commerce is the production, distribution, marketing, sale or delivery of goods/services by electronic means, the number of trusted E-Commerce sites that are opportunities for business people to transact or sell products or services. The trend of selling in e-commerce cannot be separated from the behavior of consumers who currently spend more time browsing online shopping application sites, either using their desktop or using their cellphones. Consumers who shop by browsing can feel their own pleasure in examining the existing visual elements.

E-commerce sites are not only to promote products and services but also become a place for buying and selling transactions that make money online or indirectly. According to data from ipriceinsight.com (2017), the number of well-known E-Commerce in Indonesia reaches 37 brands. For example in the fashion sector, for example, based on data from ipriceinsight.com in the fashion sector in Indonesia, there are already eighteen well-known E-Commerce brands such as Lazada, Shopee, Tokopedia, Lazada, Hijabenka, and others. In this study, researchers will examine the existence of the Shopee online store, how these e-commerce actors are able to maintain their existence in the midst of intense competition. The existence of a retail company, of course, gets a good signal from many people, because it really helps the community in fulfilling their daily needs. People have become more efficient in their shopping time, they don't need to have to shop outside the house to fulfill their daily needs which takes a lot of time to shop for their daily needs, and people also get more complete products for their daily needs from online e-commerce. Therefore, the role of retail is very important to fulfill people's daily product needs efficiently and completely.

Business people take advantage of this because shopping is a fun activity for many people and some people cannot be separated from shopping habits. Consumers who like to shop have a greater tendency to search for information about the product or service they want by browsing. As is known, there are many necessities such as fashion that are offered at Shopee and offer convenience in shopping, payment and delivery. Based on data obtained from Iprize, the top ten retailers in Indonesia are Shopee, Blibli, Tokopedia, Elevenia, Sorable, Zalora, Shopee, Bukalpak. Shopee is the most visited e-commerce website in Indonesia every month. According to IPrice data, it received 71.5 million visits in the second quarter of 2019 (www.databoks.katadata.co.id ). 
Top E-Commerce berdasarkan Ranking PlayStore Kuartal I 2017-Kuartal II 2019

\section{Sumber-iPrice, 2019}

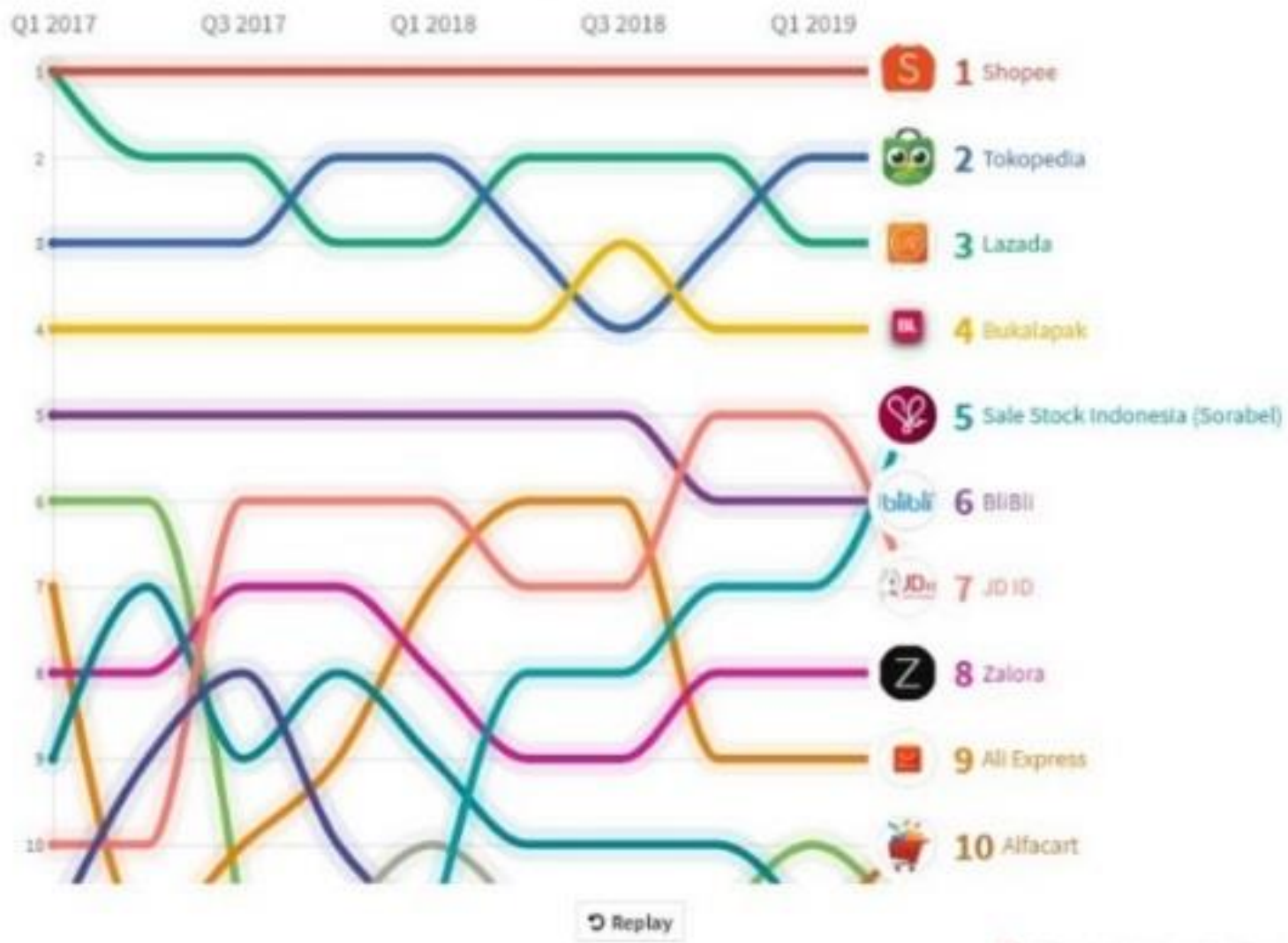

* A Rouinh data visualisabon

\section{Shopee Rankings \\ Source: Databoks iPrice 2019}

Currently, fashion products in Indonesia are changing rapidly even in a matter of days, especially fashion products. For many people fashion affects. what we wear, how we live, and how we see ourselves. Shopee also collaborates with other product brands to attract consumers. Hedonic shopping motivation is created by someone's encouragement to shop so that they are easily influenced by the latest products, shopping becomes a person's lifestyle to fulfill daily needs.

Consumer needs are very influential on the lifestyle (shopping lifestyle). With so many new products that have sprung up, consumers are always following developments. At first, most of the time when you open the Shopee application, you just look around, but in the end you will be interested in a product so that there is an unplanned purchase (impulsive buying). Consumer purchases that are impulsive buying can be realized by changes in shopping lifestyle. There are several things that can influence consumers to make spontaneous purchases (impulsive buying), 
namely hedonic shopping motivation, and shopping lifestyle. Utami (2010) defines that hedonic shopping is shopping because they want to have fun and shopping is something that is interesting, hedonic shopping is consumers shopping because they feel happy when they are shopping either directly or online. This feeling of pleasure arises from within a person because shopping can relieve fatigue from various daily activities, even though it is done by buying online, because if shopping has become a hobby in someone, even though just looking around is enough to make some people happy. which in the end just looking around makes someone interested in seeing a collection of new products that they don't have and with attractive promo offers.

According to Park (2015) the value of hedonic shopping plays an important role in impulsive buying activities, because in this case hedonic shopping can encourage consumers' desire to always do shopping not only because of need, but also the desire that arises from consumers themselves to make purchases spontaneously. Several studies also state that hedonic shopping motivation has an effect on impulsive buying, such as research by Gultekin and Ozer (2012) which states that hedonic shopping motivation has a positive and significant influence on impulsive buying, which means that the higher a person's hedonic shopping motivation, the higher the impulsive buying that occurs. Zayusman \& Septrizola's research (2019) shows that heodonic shopping motivation has a positive and significant effect on impulsive buying. However, this is not relevant to Rahmawati's research (2018) which states that hedonic shopping motivation does not have a significant effect on impulsive buying.

Hedonic shopping motivation is influenced by several factors, one of which is hedonic motives. Hedonic motives are things that can move or encourage someone to fulfill their needs for material pleasure or enjoyment as the main goal. The hedonic motif itself is created because of someone's passion in shopping which is influenced by something new or a new trend. Kosyu, Hidayat and Abdullah (2014) the reason a person has a hedonic nature is because there are many needs that cannot be met before, then after the new needs are met and sometimes these needs are met, new needs emerge and sometimes these needs are more prioritized than the previous needs. Prastia (2013) assumes that lifestyle is a feature of the modern world or what is also called modernity. Lifestyle is a pattern of action that distinguishes one person from another. The many needs for primary and secondary goods make consumers to fulfill their needs and desires, this is what underlies the creation of Shopping Lifestyle. A shopping lifestyle refers to a person's consumption patterns that reflect how they spend their time and money. Japarianto and Sugiharto (2011) reveal that shopping lifestyle shows a way that a person chooses to spend income, such as in terms of funds for various products and certain alternatives. Consumers in making or deciding to purchase are influenced by factors such as advertisements and these trends. The way people spend money and time is the reason why people make excessive purchases, such as buying products they don't need.

This excessive purchase is usually influenced by the attractive offers offered by retailers. The sense of fulfillment of one's needs and desires makes a person motivated to make purchases that were not planned in advance. Circumstances like this occur because of an internal urge so 
that they decide to buy the product without thinking about it and which may not be listed on the shopping list, this kind of behavior is usually called impulsive behavior. A person's impulsive behavior is influenced by an impulse from himself to fulfill his current needs. The existence of an impulse from a person when he sees the products offered by retailers allows someone to make an unplanned purchase (Impulse Buying). Cobb and Hoyer determine that shopping lifestyle and impulsive buying are closely related. This is relevant to the results of research conducted by Chusniasari and Prijati (2015) which revealed that there was a positive and significant relationship between shopping lifestyle and impulsive buying, but this was not relevant to research conducted by Darma and Japarianto (2014) which showed that there is no significant effect of shopping lifestyle on impulsive buying. The very rapid development of products also makes people inevitably have to follow existing trends, not even just following but has become a necessity for today's modern society. This will also have an impact on the lifestyle of modern society. The factors that influence the shopping lifestyle include research on brands, the impact of advertising, and most importantly, the personality or characteristics of the individual.

Interest in lifestyle shopping in society, especially women, is the most prominent in lifestyle. Lifestyle can confirm a person's identity to the social environment. This causes female consumers to not care and think in advance to buy the products they want, this will make it easier for them to order products through Shopee. By only using a data network or wifi, it is very easy for consumers to open the Shopee application via a smartphone and can see various products on the application anytime and anywhere. At first most of them were just looking around, but in the end they will be interested in a product, resulting in an unplanned purchase (impulsive buying). As the results conducted by Kosyu et al (2014) that the current shopping lifestyle is used to adjust social status by choosing well-known brands such as Stradivarius. Supported by the advantages of Stradivarius which has a simple, trendy and favorite fashion style for the upper middle class. Impulsive buying by spending time and money is used by some Stradivarius consumers to make excessive purchases, one of which is driven by the attractive stimulus offers offered by Stradivarius. Therefore, consumers often experience impulsive buying when driven by hedonic shopping motivation, because they assume that shopping is a pleasure in itself when what they need is fulfilled even though it is not useful for the product, in the sense that someone has their own satisfaction with the product. they've bought, so when they see another item with the same product they become interested in buying it even though they didn't have a plan from the start.

Shopping at Shopee is currently one of the hedonic shopping motivation activities favored by customers because they think that shopping will cause a feeling of pleasure, happiness, and can fill their time with shopping and with various offers offered by Shopee. Hedonic shopping motivation is a product that is created when choosing a product based on taste when shopping. A person will buy a product with a positive heart without having to plan in advance in the form of a shopping list description. Consumers really want to meet their own needs at this time, which encourages impulsive buying behavior. So with the developments in online shopping, 
especially in Shopee's e-commerce, which is increasingly having an impact on people's behavior today, especially among students. Shopee has the advantage of products that are always up to date according to current trends. In addition, the Shopee application is complete with the latest products that make it easy for consumers to access online shopping, to support consumers who like to spend time shopping. The behavior of people who shop with planned today has changed to unplanned or impulsive buying. This phenomenon can be seen in the Shopee application, which has now become a place to spend time looking for products, which provide daily necessities. They forget the purpose when visiting the Shopee application, especially the behavior of students when doing shopping activities.

\section{RESEARCH METHODS}

The study used a quantitative approach in research. Quantitative research is a process that emphasizes decision making, data interpretation, and conclusions based on numbers obtained from statistical results (Sugiyono, 2010). Quantitative research method is a research method that aims to examine certain populations or samples with sampling techniques which are generally carried out randomly, data collection using research instruments, and quantitative or statistical data analysis to test predetermined hypotheses. The population is a generalization area consisting of objects or subjects that have certain quantities and characteristics and conclusions have been drawn (Sugiyono, 2009). The population is 2404 students from the Faculty of Economics and Business, the Faculty of Teacher Training and Education, and the Faculty of Psychology, University of Muhammadiyah Gresik.

The technique used in this study using a sampling technique in this study is Non-probability sampling. Non-probability sampling technique is that all elements in the population do not have the same opportunity to be selected as samples. The non-probability sampling technique used in this study is accidental sampling. Accidental Sampling, is a sampling technique based on anyone the researcher meets accidentally where the sample meets the characteristics of the population so that it is considered suitable as a data source (Sugiyono, 2011). In this study, the samples taken were students at the University of Muhammadiyah Gresik class of 2017 (FEB, FKIP, and FPSI) who had done impulsive buying in the Shopee application. Subjects collected were 84 respondents who were willing to fill out the questionnaire via google form, but there were some that did not match the characteristics of the researcher, so the subjects were collected into 81 students. Researchers distributed questionnaires from June 24 to July 2, 2021.

The data collection technique in this study used a questionnaire (questionnaire) method which was distributed online via Google Form. Questionnaires and questionnaires are data collection techniques that are carried out by giving questions or written statements to respondents to answer (Sugiyono, 2012). The questionnaire used consists of items which the respondent then gives an assessment by filling in a check mark $(\checkmark)$ in the appropriate column. The measurement scale used is the Likert scale, which is a scale used to measure attitudes, opinions, and perceptions of a person or group of people about social phenomena. Then these 
indicators are presented as a starting point for compiling instrument items which can be in the form of questions and statements.

The data analysis technique in this study is multiple regression which is used to obtain a functional relationship between one independent variable and one dependent variable. Multiple regression analysis based on Baron and Kenny (1986) calls a variable called a mediator if the variable influences the relationship between the predictor (independent) and criterion (dependent) variables. The mediation model has a hypothesis that the independent variable affects the mediator variable, which in turn affects the dependent variable. Perfect mediation occurs when there is no effect of the independent variable on the dependent variable when the mediator variable is included in the equation. However, if the effect of the independent variable to the dependent variable decreases but is not equal to zero by including a mediator, then partial mediation occurs. Before testing the hypothesis, the researcher tested the classical assumptions first.

The steps in testing the hypothesis referring to the procedure for testing the role of the mediator proposed by Baron and Kenny (1986) are as follows:

1. Create a hedonic shopping motivation (X) regression equation for impulsive buying (Y). This regression analysis will produce a coefficient of $\mathrm{c}$. This pathway is expected to be significant $(\mathrm{p}<0.05)$.

2. Create a hedonic shopping motivation $(\mathrm{X})$ regression equation for the shopping lifestyle (M). This regression analysis will produce a coefficient. This pathway is expected to be significant $(\mathrm{p}<0.05)$.

3. Make a regression equation for shopping lifestyle (M) to shopping lifestyle (M). This regression analysis will produce a coefficient. This pathway is expected to be significant $(\mathrm{p}<0.05)$.

4. Create a hedonic shopping motivation (X) and shopping lifestyle (M) regression equation for impulsive buying $(\mathrm{Y})$. This regression analysis will produce two predictor estimation values from $M$ and $X$. Our prediction of $M$ to $Y$ produces a coefficient of $b$, while prediction of $\mathrm{X}$ to $\mathrm{Y}$ produces a coefficient of $c^{\prime}$. Path $\mathrm{b}$ is expected to be significant $(p<0.05)$, while path $c^{\prime}$ is expected to be insignificant $(p>0.05)$.

In summary, it can be written in three equations as follows:

$$
\begin{aligned}
& \text { Equation I : } \mathrm{Y}=\alpha_{1}+c \mathrm{X} \\
& \text { Equation II }: \mathrm{M}=\alpha_{2}+a \mathrm{X} \\
& \text { Equation III }: \mathrm{Y}=\alpha_{3}+c^{\prime} \mathrm{X}+b M
\end{aligned}
$$

$$
\begin{aligned}
& \text { Description: } \\
& Y=\text { Impulsive Buying } \\
& M=\text { Shopping Lifestyle } \\
& \mathrm{X}=\text { Hedonic Shopping Motivation } \\
& \alpha=\text { Regression constant coefficient value }
\end{aligned}
$$


$\mathrm{a}=$ Hedonic shopping motivation regression coefficient value on impulsive buying

$\mathrm{b}=$ The value of the shopping lifestyle regression coefficient on impulsive buying by controlling for hedonic shopping motivation

$\mathrm{c}=$ value of hedonic shopping motivation regression coefficient on impulsive buying

$\mathrm{c}^{\prime}=$ Hedonic shopping motivation regression coefficient on impulsive buying by controlling shopping lifestyle

Variable $\mathrm{M}$ is called a mediator if the following criteria are met:

1. Equation I, X significantly affects $Y$ (or c 0 )

2. Equation II, $X$ significantly affects $M($ or $a \neq 0)$

3. Equation III, M significantly affects $\mathrm{Y}($ or $\mathrm{b} \neq 0)$

If the effect of $\mathrm{X}$ to $\mathrm{Y}$ decreases to zero after entering $\mathrm{M}$ into the regression equation (or $\mathrm{c}^{\prime}$ is not significant), then perfect mediation occurs. However, if the effect of the independent variable to the dependent decreases but is not equal to zero by including a mediator (or $\mathrm{c}^{\prime}$ is significant), then partial mediation occurs.

Classical Assumption Test which was carried out before performing multiple regression analysis, namely: (1) Normality Test, (2) Linearity Test, (3) Multicollinearity Test, (4) Heteroscedasticity Test. Furthermore, in the statistical analysis process in this study using SPSS for windows 25.0 program tools to prove the validity of the data.

\section{RESULT AND DISCUSSION}

\section{Normality Test}

The normality test was conducted to determine whether the research variable data was normally distributed or not. Normality testing uses the Kolmogorov-Smirnov Exact P Value analysis technique and for its calculation using the SPSS 25 for windows program in the test has three equations, according to Mehta \& Patel (2012) can use Exact P Value, Monte Carlo P Value, and Asymptotic P Value. Most studies use Asymptotic P Value in testing the normality of a data, but this equation has several weaknesses that make the data results abnormal. This weakness is stated by Mehtta \& Patel (2012) which states that it means that the weakness caused by asymptotics is when the data is small, the data is unbalanced and poorly distributed, it will lead to inaccurate results. Therefore, in addition to using asymptotic equations, one of them can use Exact $\mathrm{P}$ Value. So this research is for normal testing of data using the Kmolgrov-Smirnov Exact P Value Test (Patel \& Mehta, 2012). The results of the normality test for the research variables are presented as follows. 


\begin{tabular}{lcc}
\hline Hedonic Shopping Motivation & 0,810 & Normal \\
& & \\
\hline Implusive Buying & 0,366 & Normal \\
\hline Shopping Lifestyle & & \\
\hline
\end{tabular}

The results of the normality test in table 1.1 above can be seen that all research variables have a significance value greater than 0.05 ( $p>0.05$ ), so it can be concluded that the research data are normally distributed.

\section{Linearity Test}

The purpose of linearity test is to determine the relationship between the independent variable and the dependent variable is linear or not. The linearity test criterion is if the significance value is greater than 0.05 ( $\mathrm{p}>0.05)$, then the relationship between the independent variable and the dependent variable is linear. The summary results of the linearity test are presented as follows:

\begin{tabular}{lcc}
\hline \multicolumn{1}{c}{ Variable } & Significance & Description \\
\hline Hedonic Shopping Motivation & 0,280 & Linier \\
& & \\
\hline Shopping Lifestyle & 0,364 & Linier \\
\hline
\end{tabular}

From the results of the linearity test in table 1.2 above, it can be seen that the significance value of Deviation from linearity is greater than 0.05 ( $\mathrm{sig}>0.05$ ), it can be concluded that all research variables are linear.

\section{Multicolinearity Test}

Multicollinearity test was conducted to determine the magnitude of the intercorrelation between the independent variables in this study. If there is a correlation, it means that there is still a multicollinearity problem. To detect the presence or absence of multicollinearity can be seen on the value of tolerance and VIF. If the tolerance value is above 0.1 and the VIF value is 
below 10, there is no multicollinearity (Sriningsih, 2018). The results of the multicollinearity test for the regression model in this study are presented in table 1.3 as follows:

\begin{tabular}{lccc}
\hline \multicolumn{1}{c}{ Variable } & Tolerance & VIF & Description \\
\hline $\begin{array}{l}\text { Hedonic Shopping } \\
\text { Motivation }\end{array}$ & 0,980 & 1,021 & $\begin{array}{c}\text { There is no } \\
\text { multicolinearity }\end{array}$ \\
\hline $\begin{array}{l}\text { Shopping Lifestyle } \\
\text { Multicoliniearity }\end{array}$ \\
\hline
\end{tabular}

From table 1.3 above, it can be seen that all variables have tolerance values above 0.1 and VIF values below 10, so it can be concluded that the regression model in this study does not occur multicollinearity between independent variables.

\section{Heteroscedasticity Test}

Heteroscedasticity testing aims to test whether in the regression model there is an inequality of variance from the residuals of one observation to another observation. A good regression model is that there is no heteroscedasticity and to determine whether there is heteroscedasticity in this study, the Spearman Rank test is used. If the independent variable is not statistically significant and does not affect the dependent variable, then there is an indication that there is no heteroscedasticity. The following are the results of the heteroscedasticity test of the regression model in this study.

\begin{tabular}{lcc}
\hline \multicolumn{1}{c}{ Variable } & Sig & Description \\
\hline $\begin{array}{l}\text { Hedonic } \\
\text { Shopping Motivation }\end{array}$ & 0,688 & $\begin{array}{c}\text { There is no } \\
\text { heteroscedasticity }\end{array}$ \\
\hline Shopping Lifestyle & 0,806 & $\begin{array}{c}\text { There is no } \\
\text { heteroscedasticity }\end{array}$
\end{tabular}

Table 1.4 shows that all variables have a significant value greater than 0.05 so it can be concluded that the regression model in this study does not occur heteroscedasticity.

\section{Hypothesis Test}

Hypothesis testing in this study aims to prove the effect of hedonic shopping motivation on impulsive buying mediated by shopping lifestyle on students who have done impulsive buying or shopping unplanned at Shopee. The results of hypothesis testing are presented as follows: 
The results of the regression analysis were used to test the effect of hedonic shopping motivation on impulsive buying. The results of the multiple linear regression test are presented in table 1.5 as follows:

Table Multiple Linear Regression Analysis Results

\begin{tabular}{|c|c|c|c|c|c|c|c|}
\hline Jalur & Model Regresi & $\mathbf{R}^{2}$ & $\mathbf{F}$ & Sig. & Beta & $\mathbf{t}$ & Sig. \\
\hline c & Regresi X ke Y & 0,361 & 44,692 & 0,000 & 0,725 & 6,685 & 0,000 \\
\hline $\mathbf{a}$ & Regresi X ke M & 0,020 & 1,633 & 0,205 & 0,116 & 1,278 & 0,205 \\
\hline b & Regresi M ke Y & 0,004 & 0,283 & 0,596 & 0,088 & 0,532 & 0,596 \\
\hline c' & $\begin{array}{l}\text { Regresi X ke Y } \\
\text { melalui } M\end{array}$ & 0,021 & 0,848 & 0,432 & $\begin{array}{l}0,136 \\
-0,027\end{array}$ & $\begin{array}{l}1,188 \\
-0,288\end{array}$ & $\begin{array}{l}0,238 \\
0,774\end{array}$ \\
\hline
\end{tabular}

Table 1.5 shows the results of the regression analysis of the mediation test of the Shopping Lifestyle variable on Hedonic Shopping Motivation with Implusive Buying. The following is the description of the analysis results:

1. Path $\mathrm{c}$ finds that hedonic shopping motivation has a significant effect on impulsive buying, indicated by a value of 0.000 ( $\mathrm{p}<0.05)$. Hedonic shopping motivation has an effect of $36.1 \%$ on impulsive buying. Hedonic shopping motivation has a positive relationship with impulsive buying.

2. Path a finds that hedonic shopping motivation does not have a significant effect on shopping lifestyle as indicated by a value of 0.205 ( $p>0.05)$.

3. Path $b$ has the result that shopping lifestyle does not have a significant effect on impulsive buying as indicated by a value of 0.596 ( $p>0.05)$. 
4. Path $\mathrm{c}^{\prime}$ found that hedonic shopping motivation on impulsive buying through lifestyle shopping did not have a significant effect, indicated by a value of 0.432 ( $p>0.05)$. This can be said to be perfect mediation because the effect of $\mathrm{X}$ to $\mathrm{Y}$ decreases to 0 after entering $\mathrm{M}$ into the regression equation (or path $\mathrm{c}^{\prime}$ is not significant).

In summary, it can be written in one equation as follows:

$$
\begin{aligned}
& \mathrm{Y}=a+\mathrm{cX} \\
& \mathrm{Y}=0,725+0,361 \mathrm{X}
\end{aligned}
$$

Description:

$\mathrm{Y}=$ Impulsive Buying

$a=$ Regression constant coefficient value

$c=$ value of hedonic shopping motivation regression coefficient on impulsive buying

In simple terms, the results of the three regression analyzes can be described in the diagram below:

\section{Regression Analysis with Mediators}

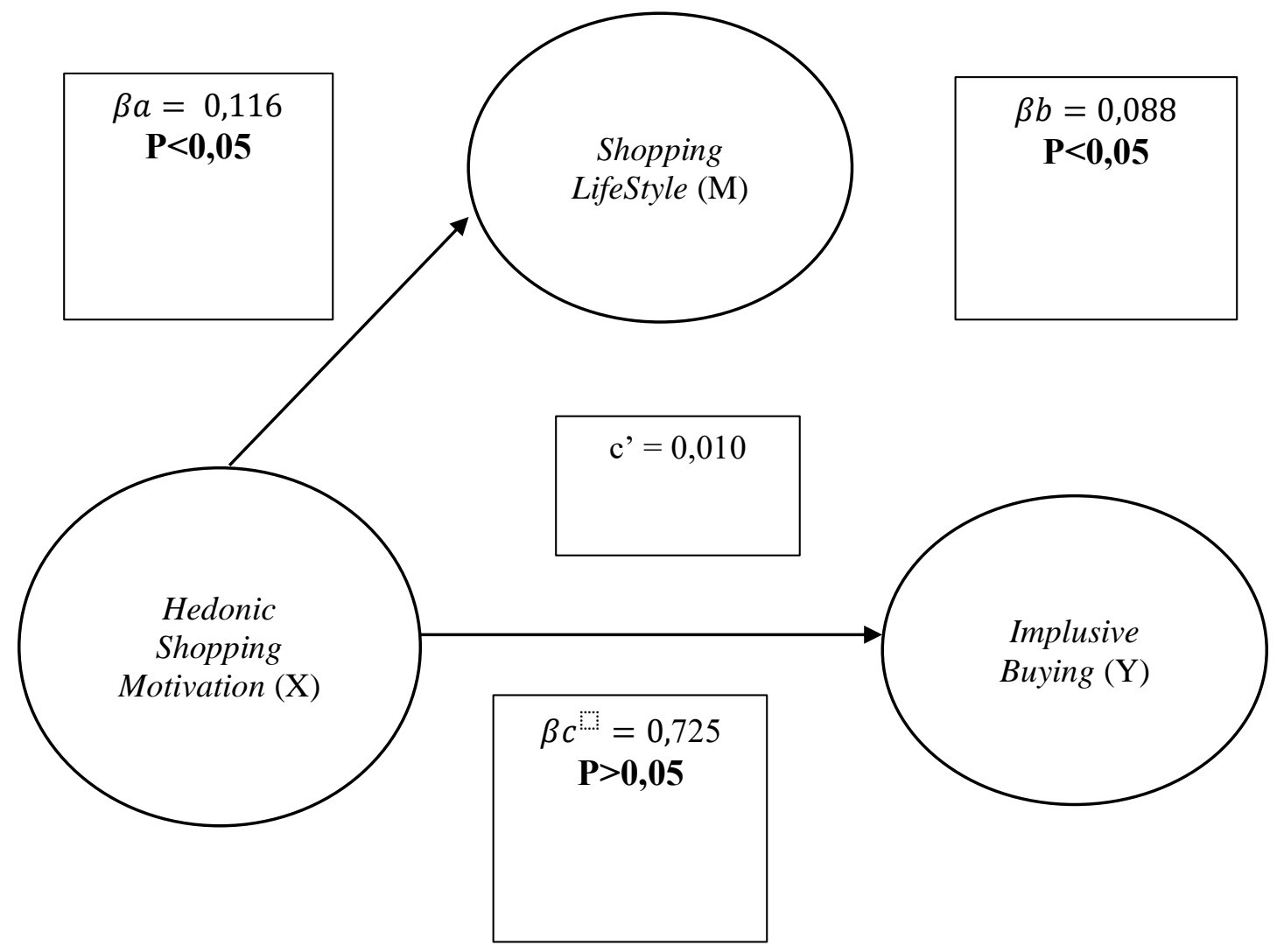


From the figure, it can also be seen that the total effect of shopping lifestyle to impulsive buying (line b) is 0.088 , the direct effect of hedonic shopping motivation to shopping lifestyle (line a) is 0.116 and the indirect effect of hedonic shopping motivation to impulsive buying (line axb) is $0.116 \times 0.088=0.010$. The total effect is the sum of the direct effects plus the indirect effects $\left(c=c^{\prime}+a b\right)$.

According to Baron and Kenny (1986) state the three steps of the regression test above are able to test the influence of the independent variable on the dependent variable with the presence of a mediator variable if it occurs in the following three conditions; (1) estimating the predictor estimation value from the regression of the dependent variable (Y) with the independent variable $(\mathrm{X})$ as the predictor. At this stage it is expected that the value is significant. (2) estimating the predictor estimation value from the regression of the mediator variable $(\mathrm{M})$ with the independent variable (X) as the predictor. At this stage, it is expected that the value is also significant. (3) regressing the dependent variable (Y) with the independent variable (X) and the mediator variable (M) as predictors. At this stage, the prediction of $\mathrm{M}$ to $\mathrm{Y}$ is expected to be significant, while the prediction of $\mathrm{X}$ to $\mathrm{Y}$ is expected to be insignificant. If these three conditions are met, then the influence of the independent variable $(\mathrm{X})$ on the dependent variable (Y) in the third equation must be smaller than the first equation so that complete mediation is obtained.

\section{DISCUSSION}

Respondents in this study were students of the Faculty of Economics and Business, Faculty of Teacher Training and Education, and the 2017 Faculty of Psychology, University of Muhammadiyah Gresik. which amounted to 2404 students, the research sample was 81 students. After the researchers carried out the classical assumption test consisting of (normality test, linearity test, heteroscedasticity test, and multicollinearity test) then the next step was to use path analysis with multiple linear regression analysis to test the effect of hedonic shopping motivation on impulsive buying with a shopping lifestyle mediator on shopee consumers.

Based on the results of the multiple linear regression test that has been carried out by the researcher, it shows that $\mathrm{R}^{2}$ shows a correlation or relationship between the dependent and independent variables. The $\mathrm{R}$ number 0.361 means that there is a strong relationship between the hedonic shopping motivation variables on impulsive buying. This is in line with previous research which states that the value of hedonic shopping motivation has an effect on impulsive buying such as research conducted by Prastia (2013) which shows that the value of hedonic shopping has a significant effect on impulsive buying. This is also relevant to the results of research conducted by Utami (2016) which shows that hedonic shopping motivation has a significant effect on impulsive buying. In a study conducted by Kosyu (2014) also stated that hedonic shopping motives have a significant effect on impulsive buying. The things that can explain $36.1 \%$ of the influence of hedonic shopping motivation on impulsive buying, namely $63.9 \%$ can influence other factors. 
The results obtained prove that hedonic shopping motivation has a direct influence on impulsive buying. The effect is $36.1 \%$. Based on the mediation test conducted, it is known that the value of $\mathrm{R}$ square is 0.361 . This shows that $36.1 \%$ of the variation from impulsive buying is explained by hedonic shopping motivation and shopping lifestyle. While the other $64.9 \%$ are influenced by variables outside this study. However, because the hedonic shopping motivation on impulse buying by controlling the shopping lifestyle is significant, the mediation in this study is perfect mediation.

The results of research conducted by Darma and Japarianto (2014) with the title Analysis of the Effect of Hedonic Shopping Value on Impulse Buying with Shopping Lifestyle and Positive Emotion as Intervening Variables at Ciputra World Mall Surabaya. This study shows that there is no significant effect of hedonic shopping value on impulse buying, there is a significant effect of hedonic shopping value on positive emotion, there is a significant effect of hedonic shopping value on shopping lifestyle, there is a significant influence of positive emotion on impulse buying., there is no significant effect of shopping lifestyle on impulse buying and there is a significant effect of shopping lifestyle on positive emotion.

The results of research conducted by Setyningrum, Arifi, and Yulianto (2016) with the title The Effect of Hedonic Motives on Shopping Lifestyle and Implusive Buying (a survey of superindo supermarket consumers who do impulsive buying). The research shows that there is an effect of hedonic motives on impulsive buying, hedonic motives on shopping lifestyle, hedonic motives has a significant and positive effect on impulse buying and shopping lifestyle.

The hedonic shopping motivation variable has a positive and significant effect on shopping lifestyle for students who have made impulse buying or unplanned purchases at Shopee. If it is seen from the positive regression coefficient, it shows that the higher the hedonic shopping motivation, the higher the shopping life style will be. According to Jackson in Japarianto and Sugiharto (2011) shopping lifestyle is an expression of lifestyle in shopping that reflects social status. Shopping lifestyle refers to consumption patterns that reflect a person's choices about how to spend time and money. Shopping lifestyle (shopping lifestyle) which has become a necessity for someone will form positive emotions in that person. When a person's shopping lifestyle has been fulfilled, positive emotions such as feelings of pleasure and joy will be formed in the person's mind.

The shopping lifestyle variable has a positive and significant effect on impulsive buying in students who have made impulsive buying or unplanned purchases at Shopee. If viewed from the regression coefficient which is positive, it indicates that the higher the shopping lifestyle, the higher the impulsive buying. Someone who experiences a relatively high sense of pleasure or joy as a result of positive emotions will spend more time shopping, then this will encourage someone to do impulsive buying (Rahmawati, 2009). This is because the existence of a shopping lifestyle that is felt at the time of shopping will affect purchasing decisions. Often lifestyle acts as a stimulus to buy, therefore, consumers who do impulsive buying often spend 
extra money or money when shopping. The results of this study support research conducted by (Chusniasari \& Prijati, 2015) which states that shopping lifestyle has a positive and significant effect on impulse buying. So it can be concluded that shopping lifestyle has an effect on impulsive buying.

The shopping lifestyle variable is a mediator variable between hedonic shopping motivation and impulsive buying. This means that when someone has a hedonic shopping motivation that is oriented towards pleasure when shopping and is driven by the shopping lifestyle that is felt by that person, then this can trigger impulsive buying. Hedonic considerations in someone with a positive mood such as feeling happy or excited when shopping can encourage the possibility of an unplanned purchase decision. This study supports research conducted by Utami (2016) which states that there is a positive and significant influence on the value of hedonic shopping on impulse buying through lifestyle. However, there is a difference in the value of the mediation coefficient between Utami's research and this study.

In this study, the direct influence of hedonic shopping motivation on impulsive buying through a shopping lifestyle mediator got perfect mediation. This means that there is a positive effect of hedonic shopping motivation on impulsive buying mediated by shopping lifestyle, but it turns out that shopping lifestyle can be a good mediating variable for hedonic shopping motivation in creating impulsive buying. Someone who has a high hedonic shopping motivation without a shopping lifestyle that is owned can encourage impulsive buying when shopping. In line with the results of Darma and Japarianto's (2014) research entitled Analysis of the Effect of Hedonic Shopping Value on Impulse Buying with Shopping Lifestyle and Positive Emotion as Intervening Variables at Ciputra World Mall Surabaya. This study shows that there is no significant effect of hedonic shopping value on impulse buying, there is a significant effect of hedonic shopping value on positive emotion, there is a significant effect of hedonic shopping value on shopping lifestyle, there is a significant influence of positive emotion on impulse buying., there is no significant effect of shopping lifestyle on impulse buying and there is a significant effect of shopping lifestyle on positive emotion. In other words, individuals with high hedonic shopping motivation with high shopping lifestyle also contribute to impulsive buying.

The results of research conducted by Nurlinda and Cristina (2019) with the title Analysis of the Role of Positive Emotion as a Mediator of Hedonic Shopping and Shopping Lifestyle, Against Impulse Buying on the Lazada Marketplace. The study showed that hedonic shopping had a positive and significant effect on positive emotion, lifestyle shopping had no effect on positive emotion, it also showed a significant effect on impulsive buying and positive emotion succeeded in being a mediator variable for hedonic shopping and impulsive buying.

In this study, although hedonic shopping motivation can directly affect impulsive buying by $36.1 \%$, but when hedonic shopping motivation on impulsive buying through shopping lifestyle gets perfect mediation results. Therefore, it can be concluded that the presence of a shopping 
lifestyle plays an important role in linking hedonic shopping motivation and impulsive buying. However, because the effect of hedonic shopping motivation on impulsive buying with a shopping lifestyle mediator is not significant, the mediation in this study does not include partial mediation. 


\section{CONCLUSION AND SUGGESTION}

Based on the analysis and discussion of the effect of the hedonic shopping motivation variable on impulsive buying mediated by shopping lifestyle on students who have done impulsive buying at Shopee, the following conclusions can be drawn:

1. The results of the $\mathrm{c}$ hedonic shopping motivation path have a positive and significant effect on impulsive buying with a value of $0.000(\mathrm{P}<0.05)$ so that Ha is accepted, Ho is rejected.

2. The results of the a hedonic shopping motivation path have no and significant effect on shopping lifestyle with a value of 0.205 ( $p>0.05$ ) so that Ho is accepted, Ha is rejected.

3. The results of path $b$ shopping lifestyle have no significant and significant effect on impulsive buying with a value of 0.596 ( $p>0.05$ ) so that Ho is accepted, Ha is rejected.

4. The results of the c'hedonic shopping motivation path on impulsive buying through lifestyle shopping have no significant effect with a value of 0.432 ( $p>0.05)$. However, it is said to be able to be a perfect mediation.

5. The results of the study, the subject has a high category on the variable of impulsive buying, a medium category on the hedonic shopping motivation variable and a low category on the shopping lifestyle variable.

Practical advice in this study was obtained based on data obtained from the frequency of respondents answers to statement items in the hedonic shopping motivation variable on impulsive buying and shopping lifestyle on Shopee consumers. These suggestions include: Shopee consumers to further minimize hedonic shopping motivation by not doing excessive shopping, shopping to see sales and price discounts. Impulsive buying can be minimized by shopping according to needs, such as determining sufficient purchases. Shopping lifestyle can be improved according to lifestyle. It is hoped that Shopee should take advantage of the motivation hedon owned by customers, so that in the future with this shopping lifestyle, Shopee can further improve through hedonis. 


\section{REFRENCES}

Anggreani, D. D., \& Suciarto, S. (2020). Pengaruh Gaya Hidup Berbelanja Dan Perilaku Hedonik Terhadap Pembelian Implusif (Studi Pada Toko Belanja Online Shopee). JEMAP: Jurnal Ekonomi, Manajemen, Akuntansi, Dan Perpajakan. 3(1): 36-39.

Anin, A., Rasimin, B. S., \& Atamimi, N. (2015). Hubungan Self Monitoring Dengan Impulsive Buying Terhadap Produk Fashion Pada Remaja. Jurnal Psikologi. 35(2): 181-185.

Arda, M., \& Andriany, D. (2019). Effect Of Loneliness And Discount Price On Impulse Buying In Teenage Grils. The 1 International Conference On Innovation Of Small Medium-Sized Enterprise. 1(1): 25-34.

Arikunto, S. (2013). Prosedur Penelitian. Jakarta: Rineka Cipta.

Arisandy, D. (2017). Kontrol Diri Ditinjau Dari Implusive Buying Pada Belanja Online. Jurnal Ilmiah PSYCHE. 11(1): 62-66.

Arnold, M. J., \& Reynlods, K. E. (2003). Hedonic Shopping Motivations. Journal Of Retailing. 79(2): 80-90.

Arnold, M., \& Reynolds, K. (2012). Approach And Avoidance Motivation: Investigating Hedonic Consumption In A Retail Setting. Journal Of Retailing. 79(2): 399-441.

Azwar, S. (2012). Reliabilitas Dan Validitas. Yogyakarta: Pustaka Pelajar.

Baron, R. M., \& Kenny, D. A. (1986). The Moderator-Moderator Variable Distinction In Social Psychological Research: Conceptual, Strategic, And Statistical Considerations. Journal Of Personality And Social Psychology. 51(6): 1173-1180.

Chusniasari, \& Prijati. (2015). Pengaruh Shopping Lifestyle, Fashion Involment Dan Hedonic Shopping Terhadap Impluse Buying Pelanggan. Jurnal Ilmu Dan Riset Manajemen. 4(12): 1-21.

Cobb, \& Hoyer. (2015). Planned Versus Impulse Purchase Behavior. Journal Of Retailing. 62(4): 69-77.

Dawson, S., \& Kim, M. (2009). External And Internal Trigger Cues Of Impulse Buying Online. Direct Marketing An International Journal. 3(1): 21-25.

Faber, R. J., \& Youn, S. (2000). Store Environment, Personality Factors And Implusive Buying Behavior In Egypt: The Mediating Roles Of Shop Enjoyment And Impluse Buying Tendencies. Journal Bussines And Management Sciencess. 3(2): 69-77.

Faiza, N. (2019). Dampak Pembelian Online Shop Di Shopee Dalam Perubahan Gaya Hidup Konsumtif Perempuan Shopaholic Di Fakultas Ekonomi Dan Bisnis Universitas Wiraraja Sumenep. Universitas Wiraraja. 17(1): 10-15.

Ghozali, I. (2006). Structural Equation Model (Smartpls) Versi 3.0. Semarang: Badan Penerbit Universitas Diponegoro.

Handayani, S. \&. (2019). Effect Of Discount And Hedonic Shopping Motives Against Buying Impulse. The 1 International Conference Pn Innovation Of Small Medium Sixed Enterprise. 1(1): 93-101. 
Hausman, A. (2000). A Multi-Method Investigation Of Consumer Motivations In Impulse Buying Behavior. Journal Of Consumer Marketing. 17(5):50-55.

Hayes, A. F. (2018). Introduction To Mediation, Moderation, And Conditional Process Analysis: A Regression-Based Approach Second Edition. New York: The Guilford Press.

Henrietta. (2018). Implusive Buying Pada Dewasa Awal Di Yogyakarta. Fakultas Psikologi Universitas Sanata Dharma Yogyakarta. 10(4): 3-5.

Horvath, C., \& Adiguzel, F. (2017). Shopping Enjoyment To The Extreme: Hedonic Shopping Motivations And Compulsive Buying In Developed And Emerging Markets Measrue Of Complusive Buying. Journal Of Bussines Research. 10(6): 80-85.

Hursepuny, C. V., \& Oktafani, F. (2018). Pengaruh Hedonic Shopping Motivation Dan Shopping Lifestyle Terhadap Impulse Buying Pada Konsumen Shopee_Id. EProceeding Of Management. 5(1): 1042-1043.

Ilmalana. (2012). Analisis Motivasi Konsumen Online Dalam Melakukan Impluse Buying Pada Transaksi C2C Commerce. Fakultas Ilmu Sosial Dan Politik Universitas Indonesia.

Japarianto, E., \& Sugiharto, S. (2011). Pengaruh Shopping Life Style Dan Fashion Involvement Terhadap Impulse Buying Behavior Masyarakat High Income Surabaya. Fakultas Ekonomi, Universitas Kristen Petra. 6(1): 30-36.

Kacen, J. J., \& Lee, J. A. (2002). The Influence Of Culture On Consumer Impulsive Buying Behavior. Journal Of Consumer Psychology. 12(2): 165-170.

Kosyu, D. A., Hidayat, K., \& Abdillah, Y. (2014). Pengaruh Hedonic Shopping Motives Terhadap Shopping Lifestyle Dan Impulse Buying (Survei Pada Pelanggan Outlet Stradivarius Di Galaxy Mall Surabaya). Jurnal Administrasi Bisnis. 14 (2): 1-10.

Lumintang, F. F. (2012). Pengaruh Hedonic Motives Terhadap Impulse Buying Melalui Browsing Dan Shopping Lifestyle Pada Online Shop. Jurnal Wima. 1(6): 23-27.

Musriha, D. (2012). Effect Of Servicescape And Employee Communication Quality On Customer Loyalty Of Mandiri Bank In Surabaya. Academic Research International. 2(1): 232-238.

Nurcholish, G. (2017). Pengaruh Shopping Lifestyle, Fashion Involvement, Hedonic Shopping Value, Dan Shop Staff Terhadap Impulse Buying Behavior Konsumen. Journal Konsumen. 10(1): 40-45.

Nurjanah, S. F., \& Kurniati, R. R. (2019). Pengaruh E-Commerce Terhadap Keputusan Pembelian Pada Belanja Online Shopee. JIAGABI. 8(3): 155-156.

Ozen, H., \& Engizek, N. K. (2014). Shopping Online Without Thinking: Being Emotional Or Rational? Asia Pacific Journal Of Marketing And Logistic. 26 (1): 79-81.

Papalia, D. E., Old, S. W., \& Fedlman, R. D. (2009). Human Development: Perkembangan Manusia. Jakarta: Salemba Humanika.

Patel, N. R., \& Mehta, C. R. (2012). IBM SPSS Exact Test.

Rahma, W. S., \& Septrizola, W. (2019). Pengaruh Hedonic Shopping Motivation Dan Shopping Lifestyle Terhadap E-Impulse Buying Mahasiswi Universitas Negeri Padang Pada Lazada. Jurnal Kajian Manajemen Dan Wirausaha. 1(1): 277-278. 
Rahmawati, A. (2018). Pengaruh Hedonic Shopping Motivation Dan Promosi Penjualan Terhadap Emosi Positif Dan Dampaknya Terhadap Pembelian Implusif Dalm ECommers Berry Benka. Jakarta: Uin Syarif Hidayatullah Jakarta.

Santrock, J. W. (2002). Psikologi Perkembangan, Jilid 2. Jakarta: Erlangga.

Sari, C. A. (2015). Perilaku Berbelanja Online Di Kalangan Mahsiswi Antropologi Universitas Airlangga. Antrounairdotnet. 4(2): 205-210.

Septila, R., \& Aprilia, E. D. (2017). Implusive Buying Pada Mahasiswa Di Banda Aceh. Psikoislamedia Jurnal Psikologi. 7(2): 173-175.

Setyningrum, F. Y., Arifin, Z., \& Yulianto, E. (2016). Pengaruh Hedonic Motives Terhadap Shopping Lifestyle Dan Impulse Buying (Survei Pada Konsumen Superindo Supermarket Yang Melakukan Impulse Buying). Jurnal Administrasi Bisnis (JAB). 37(1), 97-99.

Sugiyono. (2011). STATISTIKA Untuk PENELITIAN. Bandung: Alfabeta.

Sugiyono. (2016). Metode Penelitian Kuantitatif Dan Kualitatif $R \& D$. Bandung: PT.Alfabet. Sugiyono. (2017). Metode Penelitian Kuantitatif, Kualitatif, Dan R\&D. Bandung: Alfabeta. Sultan , A. J., Sproot, D. E., \& Joireman, J. (2012). Building Consumer Self-Control: The Effect Of Self-Control Exercises On Impulse Buying Urges. Washington State University. 23(1): 61-72.

Sumintoro, B., \& Widhiarso, W. (2015). Aplikasi Model Rasch: Untuk Penelitian Ilmu-Ilmu Sosial. Cimahi: Trim Komunikasi Publishing House.

Verplanken, B., \& Herabadi, A. G. (2001). Individual Differences In Impulse Buying Tendency: Feeling And No Thinking . European Journal Of Personality. 15(1): 72-79.

Widiyanto, I., \& Prasilowati, S. L. (2015). Perilaku Pembelian Melalui Internet. JMK. 17(2): 110-115.

Wood, M. (1998). Socioeconomic Status, Delay Of Gratification And Impulse Buying. Journal Of Economic Psychology. 19 (3): 295-320.

Youn, S., \& Faber, R. J. (2000). Impulse Buying: Its Relation To Personality Traits And Cues. Advances In Consumer Research. 27(1): 179-180. 